\title{
Farmers' willingness to pay for Sinar donkey conservation in selected districts of Metekel and Assosa zones, northwest Ethiopia: a contingent valuation study
}

\author{
AWOKE MELAK", TEKLEWELD BELAYHUN, ESHO KEFYALEW ${ }^{\star \Downarrow}$, ABEBE HAILU, AMINE MUSTEFA, \\ ABRAHAM ASSEFA \\ Ethiopian Biodiversity Institute Addis Ababa. PO. Box. 30726, Addis Ababa, Ethiopia. Tel.: +25-19-21282957, ^email: awoke.melak@yahoo.co.uk
}

Manuscript received: 31 January 2020. Revision accepted: 28 June 2020.

\begin{abstract}
Melak A, Belayhun T, Kefyalew E, Hailu A, Mustefa A, Assefa A. 2020. Farmers' willingness to pay for Sinar donkey conservation in selected districts of Metekel and Assosa zones, northwest Ethiopia: a contingent valuation study. Biodiversitas 21: 3373-3379. A survey was conducted through single field visits and interviews with 160 respondents in selected districts of Assosa and Metekel Zones, Northwestern Ethiopia, to elicit farmers' willingness to pay for Sinar donkey conservation. Two districts namely Guba and Sherkole were purposively selected from the zones based on the availability of Sinar donkey breeds. Eight representative kebeles were selected from the two districts. A total of 160 households (each district 80 households) were selected randomly. Structured and semi-structured questionnaires were prepared to collect data on socio-economic and farming system characteristics. Descriptive statistics were employed to summarize data and average means were compared using SPSS version 23.0 software. Logistic regression was applied to see the effect of independent variables on the dependent variable. The contingent valuation method was used to know farmers' willingness to pay for conservation of the Sinar donkey breed. The average willingness to pay for the conservation was 98.25 Ethiopian Birr or 3.265US dollars for the conservation program per household per annum. The cash income of the respondents influenced the willingness to pay for the conservation program. This study supports the view that the economic valuation of donkey genetic resources can assist policymakers in setting conservation priorities.
\end{abstract}

Keywords: Conservation, Sinardonkey, valuation, willingness to pay

\section{INTRODUCTION}

\section{Background and justification}

Animal genetic resources constitute an important aspect of biodiversity conservation, because of their direct value to the farmers and their indirect global value. The term animal genetic resources (AnGR) is used to include all animal species, breeds and strains (and their wild relatives) that are of economic, scientific and cultural interest to humankind in terms of food and agricultural production for the present or in the future. Animal genetic resources for food and agriculture are a subset of genetic resources (defined by the Convention on Biological Diversity as "genetic material of actual or potential value") and a specific element of agricultural biodiversity. The conservation and sustainable development of animal genetic resources are the third Strategic Priority Area of the Global Plan of Action. Conservation involves both in vivo maintenance and management of genetic diversity within livestock populations that are actively contributing to the livelihoods of their keepers or that are maintained in small numbers on research or demonstration farms and in vitro storage of genetic material that can be used at a later time to increase diversity in live populations or re-establish a population (FAO 2012)

Equines are the most important animals in the farming and transport systems of Ethiopia (Alemu et al. 2003). They are important animals to the resource-poor communities in both rural and urban areas, providing traction power and transport services at low cost, and in the remote areas of Ethiopia (Getaw and Ayana 2010). It is estimated that $75 \%$ of farms in the country are located more than a day and a half walk from all-weather roads and animals are, therefore, vital for the transportation of farm produce to the market (Niraj et al. 2014a). Donkeys (Equus asinus) are essential to the livelihoods of many households in rural and urban areas of Ethiopia, relieving families from repetitive and energy-consuming tasks. Studies have shown that apart from help in transport, donkeys play a significant role in helping to empower women in many developing nations by lessening women's work burden and by improving women's and families' livelihoods through their direct and indirect contributions (Demelash and Moges 2006).

Domestic donkeys are the least studied and neglected mammals of the world and recent studies revealed that domestication events and historical processes of domestic donkeys are still an on-going debate (Befikadu et al. 2015). Even though donkeys are important in the development of rural economy, it generally received very little scientific attention.

In Ethiopia, little comprehensive effort has been exerted to systematically conserve and utilize donkey genetic resources and the current state of knowledge on breed level characterization information is inadequate and generates low level of research interest on conservation of donkey 
genetic resources and the loss and/or decline of genetic diversity contributes major problem towards developmental interventions (Befikadu et al.2015). Donkeys used to pull plows or carts are often abandoned by their owners in favor of motorized vehicles and left to fend for themselves, forming free-roaming herds that can come into conflict with humans.

Understanding the farmers' knowledge in the management of biodiversity can help in initiating in situ conservation of the genetic. In-situ conservation of animal genetic resources on-farm can be defined as the choice by farmers to continue managing animal genetic resources in their communities, in the agro-ecosystems, where the animal genetic resources have evolved historically through processes of human and natural selection (Thrall et al. 2011).

The study addressed the following specific objectives: (i) to assess farmers' willingness to pay (WTP) for Sinar donkey genetic resources conservation, (i) to identify factors influencing farmers' willingness to pay (WTP) for Sinar donkey genetic resources conservation, (iii) to test whether the contingent valuation method (CVM) can reliably be used to estimate the individuals' willingness to pay (WTP) for animal genetic resources conservation.

\section{MATERIALS AND METHODS}

\section{The Contingent Valuation Method (CVM)}

A contingent valuation (CV) approach is used to evaluate the consumers' responses in the absence of a real purchasing situation. The CV approach allows for a direct estimation of WTP by employing different elicitation techniques (Alberini and Cooper 2000). In CV, WTP is elicited through many approaches. The most widely used formats are; open-ended approach in which the respondent is presented with alternatives of the product together with the price, and he/she is requested to choose the product together with the maximum amount he/ she would be willing to pay for a product or a service. This approach may result in a large number of zero responses and a few positive responses. If the respondent is not interested, he/she may give no responses or zero responses. If, for instance, he/ she thinks that the information on WTP will be used to set the price for the product; this is a disadvantage associated with this format (Alberini and Cooper 2000). It is also a survey-based technique for eliciting preferences for non-marketed goods in a form that allows one to estimate how survey respondents trade-off private consumption for a non-marketed good in monetary terms (Terfa et al. 2015).

It is a way of determining the value of an intangible benefit that relies on surveys of people interested in it. The survey asks people about their preferences and uses the results to assign a monetary value. Those being interviewed are asked questions to determine how much they would be willing to pay for the feature or benefit being evaluated as opposed to not having it. A flip side of the question might ask how much compensation they would require if the feature or benefit were taken away (Markgraf-Bert 2019).

\section{Description of the study area}

The study was conducted in Guba and the Sherkole districts of Benishangul Gumuz's regional state. The region has a total population of 784,345 , consisting of 398,655 men and 385,690 women; urban inhabitants number 105,926 or $13.51 \%$ of the population. With an estimated area of 49,289.46 square kilometers, this region has an estimated density of 15.91 people per square kilometer. For the entire region, 174,445 households were counted which results in an average for the region of 4.5 persons to a household, with urban households having on average 3.6 and rural households 4.7 people. The ethnic groups include the Berta (25.41\%), Amhara (21.69\%), Gumuz (20.88\%), Oromo (13.55\%), Shinasha (7.73\%) and Agaw (4.22\%). The main languages are the Berta (25.15\%), Amharic (22.46\%), Gumuz (20.59\%), Oromo (17.69\%), Shinasha (4.58) and Awngi (4.01\%). Concerning religion, $44.98 \%$ of the population is Muslim, 33.3\% are Orthodox Christians, $13.53 \%$ are Protestant and $7.09 \%$ practiced traditional beliefs. The region had a projected population of $1,127,001$ in 2018 (CSA 2007).

\section{Guba district}

Guba is one of the 20 districts in the BenishangulGumuz Region of Ethiopia. It is named after the former Sultanate of Gubba. Part of the Metekel Zone, Guba is bordered by the Abay River on the south which separates it from the Kamashi Zone, Sudan on the west, Amhara Region on the north, Dangur on the east and the southeast by the Beles River, which separates it from Wenbera. Towns in Guba include Mankush. A refugee camp for displaced persons from Sudan operated in this district at Yarenja until all of its inhabitants were repatriated and the camp was closed 28 March 2007. The main crops grown in the study area are sorghum, nut, sesame, mungbean, soybean, and okra.

\section{Sherkole district}

Sherkole is one of the 20 districts in the BenishangulGumuz Region of Ethiopia. Part of the Asosa Zone is bordered by Menge on the south, Kormuk on the west, Sudan on the north, and Kamashi Zone on the east.The major settlement in this district is Holma. The ad-damazin transit center, housing 14,431 displaced Sudanese, is also located in Sherkole. One of the highest points in Sherkole is Mount Abu Ranab, a lone peak that rises near the Abay River. Other rivers include the Tumat, a tributary of the Abay. The main crops grown in the study area are sorghum, nut, sesame, mung bean, soya bean, and okra.

\section{Sampling techniques}

Purposive sampling method was used to select kebeles (localities) and respondents were selected randomly. A sample size of 160 respondents from two districts, 80 respondents for each district were selected randomly, and from each district, 2 kebeles were selected purposively based on the availability of Sinar donkey breeds. Data were collected through group discussions with key informants and individual owner's interviews using structured and semi-structured questionnaires. 


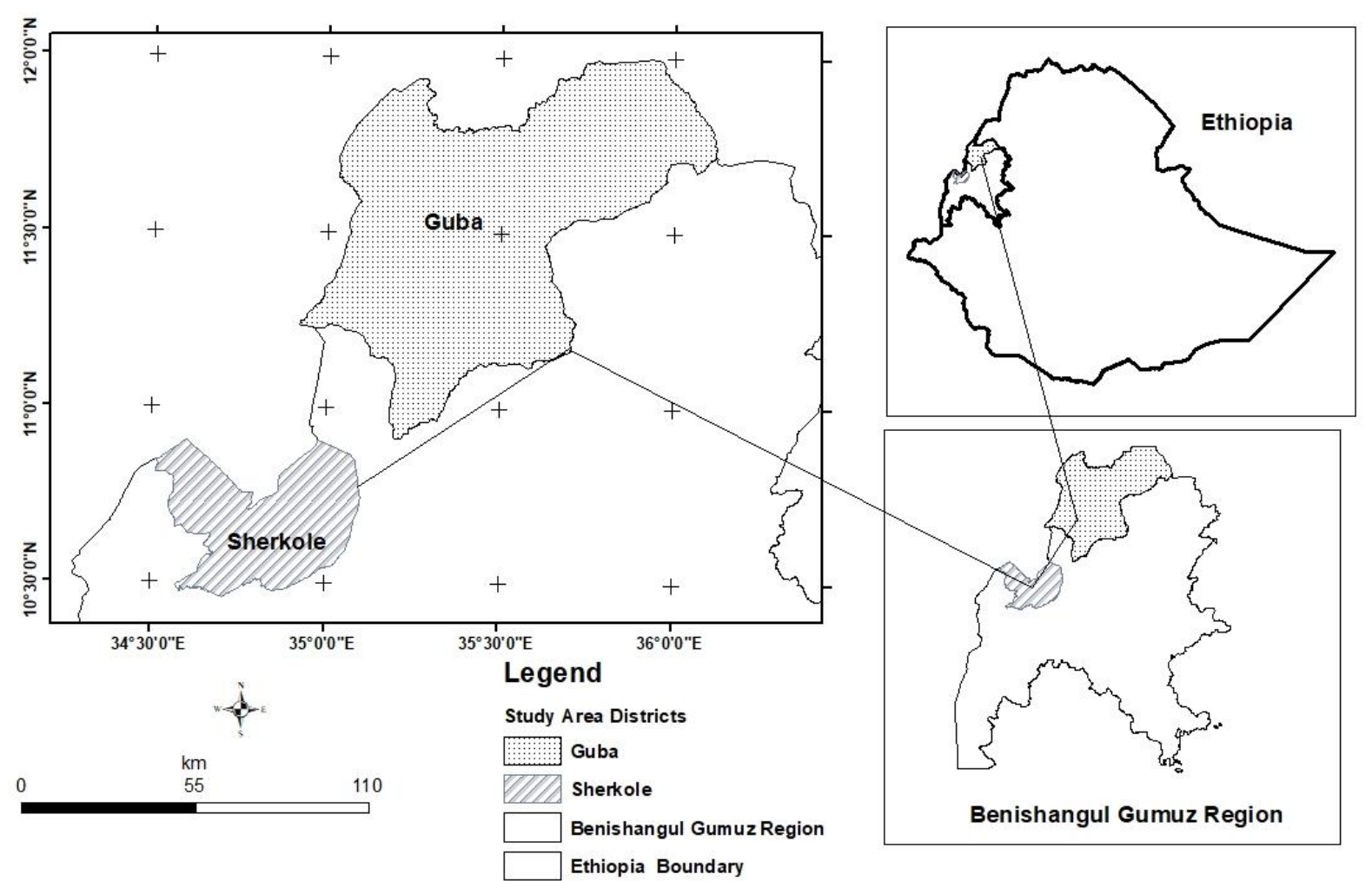

Figure 1. Map of the study area in Guba and Sherkole districts of Metekel and Assosa zones, northwest Ethiopia

Questions to check comprehension following the pretest indicated that a majority of individuals understood that this program pertained only to Sinar donkey conservation. Given the voter referendum question, the WTP question format was of the dichotomous (yes/no) type. The dichotomous choice format mimics an actual vote by simply asking whether the person would vote (e.g., pay) for the item if it would cost the household a particular Ethiopian Birr/ US dollar amount each year. In this case, the individual must just decide whether the value to him or her is worth at least this price. Since the printed Ethiopian Birr/US dollar amount varies across the sample, the dichotomous choice format allows the analyst to statistically trace out a demand relationship between the probability of a "yes" response and the Ethiopian Birr/US dollar amount.

Assuming y to represent a dichotomous variable that equals 1 , if the respondent is willing to pay and 0 otherwise.

General model of Binary Logit Regression:

$\operatorname{Ln}(Y=1) / P(Y=0)=\beta 0+\beta 1 * \mathrm{X} 1+\beta 2 * \mathrm{X} 2+\beta 3 * \mathrm{X} 3$ $+\ldots+\beta n * \mathrm{Xn}(\mathrm{I})$

Where:

$\mathrm{P}(\mathrm{Y}=1)=\mathrm{Po}$ : Probability of the households who are willing to pay

$\mathrm{P}(\mathrm{Y}=0)=1$ - Po: Probability of the households who is not willing to pay
$\operatorname{Ln} P o / 1-P o=\operatorname{Ln}($ pay $) /($ nopay $)=\beta o+\beta 1 * \mathrm{X} 1+\beta 2$ $* \mathrm{X} 2+\beta 3 * \mathrm{X} 3+\ldots+\beta \mathrm{n} * \mathrm{Xn}$

In this study, the model I, the model is simply illustrated by the following formula:

$$
Y=\beta 0+\beta i^{*} X i+u i
$$

Where:

$\mathrm{Y}$ : the dependent variable takes 1 if the answer is "yes" and take 0 if the answer is "no"

$\mathrm{Xi}$ : the independent variable and $\beta 0$ is the intercept of the regression;

ui : error term

\section{Method of data collection}

Information was gathered accompanied by a face to face interview. Focus group discussion and key informant interviews were also conducted as part of the data collection method for qualitative primary data. Moreover, secondary data like the human population of the district, altitude, and current status of the donkeys were collected from journals and agriculture offices of the Guba and Sherkole districts. The questionnaire was administered in two sections. The first section incorporated demographic, socioeconomic and perception of respondents about the benefits of the donkey. The second section contained a contingent valuation scenario and the household's WTP for the conservation of Sinar donkey. The questionnaire was 
translated into the local language (Amharic) to ease the data collection process. Then, well-trained local enumerators who are kebele livestock experts and who have good experience in the survey were employed to gather the data required for this study. The actual survey was conducted between September and October 2019. Dichotomous choice format CVM studies are preceded by a pretest survey of the small sample population. Hoyos and Mariel (2010) indicated that the pretest survey with openended questions can help to provide some information on the bounds of respondents' WTP. As a result, the pretest survey was conducted before the actual survey.

Focus group discussion and key informant interviews were held to determine initial bids in terms of cash and labor using open-ended contingent valuation format. Key informants were selected through discussion with the district experts and elders that were supposed to prove full information about the Sinar donkeys. As a result, 60, 120, 180 and 240 Ethiopian Birr per annum followed by openended questions were used as a starting bid for the actual survey. After the bids were designed, the respondents were asked a yes/no question to elicit their willingness to pay. If his/her answer was yes, the next higher amount was asked to state their answers. Finally, the respondents were asked their maximum willingness to pay both for the bounded and unbounded values using open-ended questions to state the maximum amount they were willing to pay. If his/her answer was no, the next minimum amount followed by open-ended questions was also employed to solicit his/her maximum amount. The wealth status categories were identified by using respondents' criteria. Households having more than 0.75 ha of land, being almost food selfsufficient, having permanent monthly income sources or remittances, and owning land or house in towns were considered 'rich'. Households having 0.25-0.75 ha of land, more than 6 months of food self-sufficiency, and off-farm income sources were considered 'medium category'. Households with less than 0.25 ha of land, less than 6 months of food self-sufficiency, and who are laborers employed by other farmers were categorized as 'poor' (Rana et al. 2000).

\section{Data analysis}

The data were entered in Microsoft excel 2010 and analyzed usingSPSS 23 software. A binomial logistic regression model was used to analyze the dependent variable. Descriptive statistics of SPSS 23.0 software were used to describe the survey. The study area was mapped with quantum GIS (QGIS 3.10.0).

\section{RESULTS AND DISCUSSION}

\section{Individual and household characteristics of the respondents}

The socio-economic characteristics of respondents generated in the study area are shown in Table 1. The data generated include information on gender, age, educational status, wealth status and movement of the respondents. The average age of respondents was $42.23 \pm 12.38$ years and the average family size was $7.75 \pm 4.51$ persons and the minimum family size was 1 and the maximum was 29 persons per household. The average household size was 7.75 which is higher than the national average at 5.1 (CSA 2013). The maximum number of family size in this study is that one person has up to three wives and has many children from the three wives. Out of 160 respondents, 157 $(98.1 \%)$ were males and the rest $(1.9 \%)$ were females. Out of 160 respondents, $25(15.6 \%)$ were illiterates, $83(51.9 \%)$ were literates without formal education, 29 (18.1\%) completed primary school, $7(4.4 \%)$ completed secondary school (completed grade 10), $14(8.7 \%)$ completed grade 12) and 2 respondents completed grade 12 and above. The average landholding of the respondents was 4.82 ha which is higher than the national average at 1.37 ha (CSA 2013). From the total respondents, $60(37.4 \%)$ were rich, 58 $(36.3 \%)$ were poor and the rest $42(26.3 \%)$ were medium. From the total respondents, $146(91.3 \%)$ were fixed at a place, meaning they did not move from place to place seasonally and the rest $14(8.8 \%)$ shifts from place to place (Table 1).

\section{Willingness to pay for Sinar donkey conservation}

Ninty five percent of the respondents were willing to pay money for the conservation of Sinar donkey (Table 2). The remaining respondents were not willing to make contributions to the conservation program aimed to start a Sinar donkey in-situ conservation program, to prevent Sinar donkey from decreasing in number. The reason of the respondents for unwilling to pay was $3(1.88 \%)$ "I do not earn enough money that I can pay for the conservation program", 4 (2.5\%) "I do not believe that the money I will pay will be used for Donkey Conservation", and the rest 1 $(0.63 \%)$ "I do not think the conservation of donkey is worth doing".

The average WTP for the conservation of Sinar donkey by the respondents in the form of income foregone was equivalent to USD $3.265 \pm 1.94$ per household per annum. This is the farmers' willingness to forgo benefits from the donkey by keeping them.

\section{Factors influencing Willingness to Pay (WTP)}

The variables that could potentially affect the farmers' willingness to pay for conservation of Sinar donkey were regressed with WTP bids by using binary logistic regressions. In this study, the cash income of respondents significantly $(\mathrm{P}=0.021)$ affected the willingness to pay (WTP). As other things remain constant, as the cash income of a respondent increased, the amount of money that respondents could pay for the Sinar donkey conservation activities increased by 0.139 among the total respondents (Table 3 ). 
Table 3. Result of binary logistic regression analysis $(\mathrm{N}=160)$

\begin{tabular}{|c|c|c|c|c|c|c|c|c|}
\hline \multirow[t]{2}{*}{ Variables } & \multirow[t]{2}{*}{ B } & \multirow[t]{2}{*}{ S.E. } & \multirow[t]{2}{*}{ Wald } & \multirow[t]{2}{*}{ Df } & \multirow[t]{2}{*}{ Sig. } & \multirow[t]{2}{*}{$\operatorname{Exp}(B)$} & \multicolumn{2}{|c|}{ 95\% C.I. for EXP (B) } \\
\hline & & & & & & & Lower & Upper \\
\hline Age & 0.042 & 0.041 & 1.067 & 1 & 0.302 & 1.043 & 0.963 & 1.131 \\
\hline Gender & -18.221 & 21930.444 & 0.000 & 1 & 0.999 & 0.000 & 0.000 &.- \\
\hline famsize & 0.033 & 0.124 & 0.069 & 1 & 0.793 & 1.033 & 0.810 & 1.318 \\
\hline Landholding & 0.012 & 0.102 & 0.014 & 1 & 0.906 & 1.012 & 0.830 & 1.235 \\
\hline Education & 0.141 & 0.354 & 0.158 & 1 & 0.691 & 1.151 & 0.575 & 2.306 \\
\hline Livestock & -0.010 & 0.029 & 0.114 & 1 & 0.736 & 0.990 & 0.936 & 1.048 \\
\hline Income & -1.975 & 0.858 & 5.295 & 1 & $0.021 * *$ & 0.139 & 0.026 & 0.746 \\
\hline Foodsuff & -0.138 & 0.634 & 0.047 & 1 & 0.828 & 0.871 & 0.252 & 3.019 \\
\hline Training & 0.985 & 2.024 & 0.237 & 1 & 0.627 & 2.677 & 0.051 & 141.316 \\
\hline understanding & 0.453 & 1.593 & 0.081 & 1 & 0.776 & 1.573 & 0.069 & 35.725 \\
\hline Constant & 21.718 & 21930.444 & 0.000 & 1 & 0.999 & 2703776585.085 & & \\
\hline
\end{tabular}

Note: * Significant at $\mathrm{P}=0.05$. Age, gender, famsize (family size), education (educational status), livestock (number of livestock), Income (cash income), Foodsuff (food sufficiency), training (training in animal conservation activities), understanding (the level of understanding of the future generation) of respondents

Table 4. The economic value of Sinar donkey

\begin{tabular}{|c|c|c|c|c|c|c|}
\hline Districts (L) & $\begin{array}{c}\text { Total population } \\
\text { (M) } \\
\end{array}$ & $\begin{array}{c}\text { Percent of protest zero in each } \\
\text { district }(\mathrm{N})\end{array}$ & $\begin{array}{l}\text { Expected households to } \\
\text { have a protest zero }(0)\end{array}$ & $\begin{array}{c}\text { Expected households with } \\
\text { valid responses (P) }\end{array}$ & $\begin{array}{c}\text { Average mean WTP } \\
(Q)\end{array}$ & $\begin{array}{c}\text { Aggregate benefit (in } \\
\text { Money) (R) }\end{array}$ \\
\hline Guba & 19,992 & 1.5 & 299.88 & 19692.88 & 87Birr/2.9 USD & 57109.352 \\
\hline Sherkole & 21,138 & 2.37 & 500.97 & 20637.03 & 109.5 Birr/3.63USD & 74912.4189 \\
\hline Average mean & & & & & 98.25Birr/3.265USD & 66010.88545 \\
\hline
\end{tabular}

Note: L. The list of districts included in the study. M. Total population of the districts. N. Percent of protest zeros (not willing to pay) in each district for the planned Sinar donkey conservation activities. O. $3.87(1.52 .37 \%)$ of our 160 sampled households were protest zeros (Guba1.5\% and Sherkole $2.37 \%$ ). It is calculated by multiplying the percentage of sampled protest zeros with the total population $\left(\mathrm{M}^{*} \mathrm{~N}\right)$. P. The expected number of households that are expected to protest for the proposed project. It is calculated as (M-O). Q. The average willingness to pay calculated from the maximum amount of money that a respondent could pay for Sinar donkey conservation activities in a year. R. Average mean multiplied by expected households with valid responses to the proposed program measured in money $\left(\mathrm{P}^{*} \mathrm{Q}\right)$ 
Table 1. Socioeconomic characteristics of respondents

\begin{tabular}{|c|c|c|c|}
\hline Variable & & Frequency & Percent \\
\hline $\begin{array}{l}\text { Age group } \\
\text { (years) }\end{array}$ & $\begin{array}{l}20-29 \\
30-39 \\
40-49 \\
50-59 \\
60-69 \\
70-79 \\
80-89\end{array}$ & $\begin{array}{c}18 \\
60 \\
48 \\
19 \\
7 \\
6 \\
2\end{array}$ & $\begin{array}{c}11.3 \\
37.1 \\
30.2 \\
12 \\
4.4 \\
3.8 \\
1.2\end{array}$ \\
\hline Gender & $\begin{array}{l}\text { Male } \\
\text { Female }\end{array}$ & $\begin{array}{c}157 \\
3\end{array}$ & $\begin{array}{c}98.1 \\
1.9\end{array}$ \\
\hline $\begin{array}{l}\text { Educational } \\
\text { status }\end{array}$ & $\begin{array}{l}\text { Illiterates } \\
\text { Literates without formal } \\
\text { education } \\
\text { Primary (completed } \\
\text { grade 5) } \\
\text { Secondary (completed } \\
\text { grade 10) } \\
\text { Higher secondary } \\
\text { (completed grade 12) } \\
\text { University education } \\
\text { (above grade 12) }\end{array}$ & $\begin{array}{l}25 \\
83 \\
29 \\
7 \\
74 \\
\\
2\end{array}$ & $\begin{array}{c}15.6 \\
51.9 \\
18.1 \\
4.4 \\
8.7 \\
1.3\end{array}$ \\
\hline $\begin{array}{l}\text { Wealth } \\
\text { status }\end{array}$ & $\begin{array}{l}\text { Rich } \\
\text { Medium } \\
\text { Poor }\end{array}$ & $\begin{array}{l}60 \\
42 \\
58\end{array}$ & $\begin{array}{l}37.4 \\
26.3 \\
36.3\end{array}$ \\
\hline $\begin{array}{l}\text { Movement } \\
\text { Total }\end{array}$ & $\begin{array}{l}\text { Fixed at a place } \\
\text { Move from place to place }\end{array}$ & $\begin{array}{c}146 \\
14 \\
160 \\
\end{array}$ & $\begin{array}{c}91.3 \\
8.8 \\
100 \\
\end{array}$ \\
\hline
\end{tabular}

Table 2. The frequency of bids of WTP (in Ethiopian Birr) per month

\begin{tabular}{ccc}
\hline $\begin{array}{c}\text { Bids of WTP } \\
\text { (Ethiopian Birr) }\end{array}$ & Frequency & Percent \\
\hline 0 & 8 & 5.0 \\
5 & 76 & 47.5 \\
10 & 53 & 33.1 \\
15 & 14 & 8.8 \\
20 & 9 & 5.6 \\
Total & 160 & 100.0 \\
\hline
\end{tabular}

Note: Zero indicates that the respondents were not willing to pay One US dollar is equivalent to thirty Ethiopian Birr (Commercial Bank of Ethiopia, September 2019)

\section{Discussion}

The result showed that $95 \%$ of the respondents were willingness to pay for the conservation activities of Sinar donkey by money. The remaining (5\%) of the respondents did not agree to pay money to the conservation program. The positive response of the respondents might be due to the decreasing number of Sinar donkey breeds as well as the great economic importance of the breeds to the community. The respondents agreed to pay an average of USD 3.265 per household per annum for the planned conservation activities of Sinar donkey that has an aggregate benefit of 66010.88545 US dollars. The average willingness to contribute to the conservation of Sinar donkey in the form of income foregone was greater than Gauchan (1999) result which is US dollar 3.14 per annum estimated by the cost per house hold to conserve one local landrace. So the willingness to pay for the conservation of Sinar donkey was very high, they were highly motivated to conserve the Sinar donkey breeds, due to its importance on their day to day activities.

The effect of gender of the respondents was not significant, but the negative sign of the result indicated that as the number of male respondents increased, their WTP decreased $(5 \%$ of male respondents said "no" to the conservation activity). even if the number of female respondents was less than male respondents due to purposive sampling, only the respondents who had Sinar donkey breeds were interviewed. The female respondents were more willing to pay than male respondents. This study outcome showed the elasticity of gender to willingness to pay, revealing a higher probability of willingness of female respondents to pay for conservation than their male counterparts. The finding is not in line with the findings of Wang and Jia (2012), and Hejazi et al. (2014) who found a positive relationship between male gender and WTP.

The family size of the respondents didn't have a significant effect on the conservation program. This result is in line with Neda (2015) reported family size had a negative influence on WTP for conservation activities.

The educational status of the respondents was not significant either for the Sinar donkey conservation program. This study is not in line with many studies where education plays a significant role in determining the willingness to pay (Baral et al. 2008; Wang and Jia 2012; Hejazi et al. 2014) who reported that those with a university level of education have a higher probability of willingness to pay than those with a non-university level of education. There was positive relationship between the level of education and the willingness of the visitors to pay for conservation

In this study, the cash income of respondents significantly ( $\mathrm{P}=0.021)$ affected the willingness to pay (WTP). As other things remain constant, as the cash income of a respondent increased, the amount of money that respondents could pay for the Sinar donkey conservation activities increased by 0.139 among the total respondents. As expected, annual income had a statistically significant and positive effect on the households' willingness to pay in terms of cash (Table 3). This implies that the higher the income of the respondents, the higher the maximum amount they are willing to pay for the conservation of Sinar donkey. This also proves that the amount of high-income respondents is willing to pay for Sinar donkey conservation is expected to be more in comparison to lower-income respondents. This is because having more income increases the paying power of sample respondents. This result is in agreement with the findings of previous studies (Cho et al. 2005; Xin-Liu 2009; Asikini and Isabelita 2011; Tang et al. 2013; Mekdes 2014).

Other factors such as number of livestock in the household, food sufficiency, training in animal genetic resource conservation activities and understanding of the 
future generation were not significant factors for willingness to pay, but the positive sign of training in animal genetic resource conservation and understanding/ care of the future generation indicated that participation of respondents in training was positively related to the probability of saying "yes" in the questions. In general most of the tested variables were not significantly related to the willingness to pay, while the farmers that had high cash income were significantly more willing to contribute to the conservation of Sinar donkey conservation program.

The study concluded that most of the respondents were willing to pay for the conservation of the breed. So, there must be a well-organized program regarding, the conservation of Sinar donkey breeds. Currently, the numbers of Sinar donkeys are decreasing at an alarming rate due to instability of the area; therefore, there must be attention on the peace and stabilities of the area to prevent the Sinar donkey breeds as well as other animal genetic resources from extinction.

\section{ACKNOWLEDGEMENTS}

The authors would like to thank everyone who has contributed to this study, especially Guba and Sherkole district of Ethiopia farmers and livestock experts. We would also like to thank Berhan Asmamaw for providing very constructive comments from the beginning to the end of the study. We also would like to thank Tadese Hunduma for his support for the preparation of the map of the study area.

\section{REFERENCES}

Alberini A, Cooper J. 2000. Applications of the Contingent Valuation Method in Developing Countries: A Survey. Food, and Agriculture Organization of the United Station, Rome.

Alemu G, Azage T, Alemu Y. 2003. Research Needs for Donkey Utilization in Ethiopia. [Thesis]. Debre Zeit Agricultural Research Centre, Alemaya University of Agriculture, Alemaya. [Ethiopia]

Asikini Y, Isabelita Pa. 2011. Willingness to pay for the conservation of flooded forest in the Tonle Sap Biosphere Reserve, Cambodia. Intl J Environ Rural Develop 2 (2): 1-5.

Baral N, Stern MJ, Bhattarai R. 2008. Contingent valuation of ecotourism in the Annapurna conservation area, Nepal: Implications for sustainable park finance and local development. Ecol Econ 66 (2-3): 218-227. DOI: 10.1016/j.ecolecon.2008.02.004.

Befikadu Z, Kiflay W, Sanjoy KP. 2015. Conservation of indigenous donkey breeds Ethiopia. Intl J Interdiscip Multidisciplinary Stud 3 (6): $13-22$.

CSA [Central Statistical Agency]. 2013. Agricultural Sample Survey for 2013/14: Report on Area and Production of Major Crops for Private Peasant Holdings, Meher Season. Statistical Bulletin No 532, Addis Ababa. [Ethiopia]
CSA [Central Statistical Agency]. 2007. National Population Statistics. Federal Democratic Republic of Ethiopia, Central Statistical Authority, Addis Ababa. [Ethiopia]

Cho SH, Newman DH, Bowker JM. 2005. Measuring rural homeowners' willingness to pay for land conservation easements. For Policy Econ 7 (5): 757-770. DOI: 10.1016/j.forpol.2005.03.007

Demelash B, Moges W. 2006. Causes and factors associated with occurrence of external injuries in working equines in Ethiopia. Intl $\mathbf{J}$ Appl Res Vet Med 4: 1-7.

Food and Agricultural Organizations the united nation (FAO). 2012. Cry conservation of animal genetic resources. FAO Animal Production and Health Guidelines No. 12, FAO, Rome.

Gauchan D. 1999. Economic valuation of rice landraces diversity: a case study of Bara eco site, Terai, Nepal. In: Sthapit B, Upadhyay M, Subedi A (eds.). A scientific basis of in situ conservation of agrobiodiversity on farm: Nepal's contribution to global project. NP working paper 1/99: 129-148.

Getaw A, Ayana D. 2010. Study on strongyles and parascaris parasites population in working donkeys of Central Shoa, Ethiopia. [Thesis]. Addis Ababa University, Ethiopia. [Ethiopia]

Hejazi R, Shamsudin MN, Rahim KA. 2014. Measuring the economic values of natural resources along a freeway: a contingent valuation method. J Environ Plann Manag 57 (4): 629-641. DOI: 10.1080/09640568.2012.758628

Hoyos D, Mariel P. 2010. Contingent valuation: past, present and future. Prague Econ Pap 4: 329-343.

Markgraf B. 2019. The Contingent Valuation Method. http: //smallbusiness.chron.com/contingent-valuation-method-66479.html.

Mekdes T. 2014. Analysis of Visitors Willing to Pay for the Recreational Use Value of "Menagesha Suba" Forest Park: Application of Contingent Valuation Method. [Thesis]. Addis Ababa University, Addis Ababa, Ethiopia.

Neda A, Seyed FE, Asghar F, Kamran A, Hamid Amirnejad. 2015. Estimation of the conservation value of myrtle (Myrtus communis) using a contingent valuation method: a case study in a Dooreh forest area, Lorestan Province, Iran Forest Ecosystems. Lorestan Province, Iran. For Ecosyst 2: 30. DOI: 10.1186/s40663-015-00516.

Niraj K, Alemayehu E, Berihu G, Endale B. 2014a. Reproductive performance of local and HF crossbred dairy cows in Gondar, Ethiopia. IOSR J Agric Vet Sci 7 (1): 56-61.

Rana RB, Rijal DK, Gauchan D, Sthapit B, Subedi A, Upadhyay MP, Pandey YR, Jarvis DI. 2000. In situ crop conservation: Findings of agro-ecological, crop diversity, and socio-economic baseline survey of Begnas ecosite, Kaski, Nepal. NP working paper 2/2000

Tang Z, Nan ZZ, Liu J. 2013. The willingness to pay for irrigation water: a case study in Northwest China. Global Nest J 15 (1): 76-84. DOI: 10.30955/gnj.000903.

Terfa ZG, Garikipati S, Dessie T, Lynch S, Wigley P, Bettridge JM, Christley RM. 2015. Farmers' willingness to pay for a village poultry vaccine service in Ethiopia: prospect for enhancing rural livelihoods. Food Sec 7: 905-917.

Thrall PH, Oakeshott JG, Fitt G, Southerton S, Burdon JJ, Sheppard A, Ford DR. 2011. Evolution in agriculture: the application of evolutionary approaches to the management of biotic interactions in agroecosystems. Evol Appl 4 (2): 200-215. DOI: 10.1111/j.17524571.2010.00179.x

Wang PW, Jia JB. 2012. Tourists' willingness to pay for biodiversity conservation and environment protection, Dalai Lake protected area: Implications for the entrance fee and sustainable management. Ocean Coast Manag 62: 24-33. DOI: 10.1016/j. ocecoaman.2012.03.001

Xin L. 2009. Willingness to pay among households to prevent coastal resources from polluting by oil spills: A pilot survey. Mar Pollut Bull 58: 1514-1521. 